\title{
Manipulation of "Surfer-8" Program as an Aid for Analysis of Cereal Crop Competition Experiments
}

\author{
Sami Mohemmed Amin Maarof \\ Dept.t of Field Crops, College of Agriculture, Univ. of Salahaddin - Erbil ,KRG-Iraq
}

\begin{abstract}
It is difficult to establish any agronomic practice programs for wheat (Triticum durum L.) production in Kurdistan region because of unpredictable variation in rainfall. Both of seeding rate and seeding depths are important aspects of management since they can be controlled practically. This study was conducted for two basic purposes $1^{\text {st }}$ to determine the combinations of seeding rates, and depths to achieve optimum yield potential under local conditions, $2^{\text {nd }}$ to test the possibility of manipulating Surfer-8 program as an aid of data analysis. A field experiment was conducted under rainfall and complementary irrigation conditions at Ainkawa experimental station $\left(36^{\circ} 15^{\prime} \mathrm{N}, 43^{\circ} 50^{\prime} \mathrm{E}\right)$ during the growing season, 2009-2010. Four seeding rates $4.5 \mathrm{~g}, 6.0$ $\mathrm{g}, 7.5 \mathrm{~g}$ and $9 \mathrm{~g}$ of seeds $\mathrm{m}^{-2}$ with three planting depths of 2,4 and $6 \mathrm{~cm}$ for durum wheat variety "Semito". Seeding depths and Seeding rates affected all the studied traits of tiller plant ${ }^{-1}$ flag leaf length, plant leaf, leaf area index, number of spikes $\mathrm{m}^{-2}$, number of grains spike ${ }^{-1}, 1000$ grain weight and yield. The highest grain yield obtained at the interaction of ( $4 \mathrm{~cm}$ depth $\times 7.5 \mathrm{~g}$ seeds $\left.\mathrm{m}^{-2}\right)$.Surfer8-2002, and SAS -2002 programs were used efficiently in data presentation and determination of polynomial equations, correlation coefficient. We concluded that the optimal effect of seeding depth and Seeding rate on Semito wheat response does not stay on just a single result, but could have the same value through multiple combinations expressed by contour lines. The author calls to expand the usage of Surfer programs in biological studies as well as it is used already in the engineering.
\end{abstract}

Abbreviations; TKW one thousand grain weight. Response; any of the studied traits.

\section{Introduction}

Different attempts were carried out to study the relation between seeding rates, seeding depths ,and their interaction on growth, yield component and yield of wheat due to importance and controllability of these two factors in agriculture management practices (Khan et all 2011).Previous researches present dependent factor response to independent factors mostly in a single or few results While Surfer-8 program shows Isolines that connect points with the same value of response represented in a three dimensional function $\mathrm{x}, \mathrm{y}$ and $\mathrm{z}$ modified in this paper to (seeding depth, seeding rate, and response) .Surfer-8. 2002 utilized as a procedure in data analysis and representation of the current research, then compared to SAS procedure as a key factor (SAS Institute 2002). Seeding rate and seeding depth are two of the major factors determining the ability of the crop to capture resources ( Anter. 2010 ).Seeding rate is of a particular importance in wheat production because it is under the farmer's control in most cropping systems (4). In this paper, we studied the possibility of replacing the usual methods of data analysis by some technical methods using surface8 program of superior abilities to represent three dimensional data (1). Our modification was to represent the two independent variables (density and depth) by (X axis), and ( $\mathrm{Y}$ axis) respectively, then representing responses or dependent variables (studied traits) by ( $\mathrm{Z}$ axis).

\section{II-1- Field experiment}

\section{Materials and Methods}

A field experiment was conducted under rainfall and complementary irrigation conditions at Ainkawa experimental station / Erbil $\left(36^{\circ} 15^{\prime} \mathrm{N}, 43^{\circ} 50^{\prime} \mathrm{E}\right)$ during wheat growing seasons of 2009 and 2010 . The study included five seeding rates $4.5,6,7.5$ and $9 \mathrm{~g}$ of seed weight $\mathrm{m}^{-2}$ with three planting depths $2,4,6 \mathrm{~cm}$ for durum wheat variety " Semito" wheat cultivar was seeded in field . Meteorological data was record by MOE as shown in table 1 . The soil was silty clay composed of $6.9 \%$ sand, $52.6 \%$ silt, $40.5 \%$ clay, with $0.67 \%$ organic matter, $0.52 \%$ total $\mathrm{N}, 0.27 \%$ total phosphorus, $0.47 \mathrm{~m} \mathrm{~mol} \mathrm{~L}^{-1} \mathrm{~K}^{+}$, and a $\mathrm{pH}$ of 7.22 , at $15^{\text {th }}$ October 2009 , and established in the growing seasons of 2009 and 2010 as a complete factorial RCBD design with 25 combination in three replicates, depending on local rainfall and supplementary irrigation .Analyzed through each of SAS and Surfer-8 programs separately. Meteorological records are shown in table 1, further observation were recorded for vegetative, yield and yield components Number of tillers plant ${ }^{-1}$ at scale S20 on Zadoks 1974, Leaf Area ( LA) $\mathrm{cm}^{2}$ plant $^{-1}$, Leaf Area Index (LAI) according Marof 2008, no of spikes $\mathrm{m}^{-2}$, no of Grain spike ${ }^{-1}, 1000$ grain weight (TKW) $\mathrm{g}$ using Seedmat-100 counter, grain Yield $\mathrm{g} \mathrm{m}^{-2}$ through weighing grain probes from nine 
randomly thrown quadrants of $(33.3 \mathrm{~cm} \times 33.3 \mathrm{~cm})$ size. At $3^{\text {rd }}$ June 2010 , straw weight $\mathrm{g} \mathrm{m}^{-2}$ weighed on $10 \%$ moisture content, harvest index (HI)

\section{II-2- Surfer-8 program}

The Surfer-8 program is developed by golden software, Incorporation as a mapping device (Surfer-8. 2002) .It has the ability of presenting three dimensional data (3D) as a contour line, wireframe structure, grid vector, Image, post and base maps, and scatter data interpolation, but only the first couple of mapping styles and regression were manipulated in this research. The author adopted this program believing that more obvious figures could be handled to express each of the dependent factors on ( $\mathrm{Z}$ axis), and the independent factors on both of ( $\mathrm{Y}$ axis) and ( $\mathrm{X}$ axis). This engineering program might be used in field crop science for the first time, in Iraq, at least.

\section{III-A- Effect of seeding depths and Seeding rates \\ III-A-1- Tiller Plant ${ }^{-1}$}

\section{Results and discussion}

Table-2 shows that seeding depths differed significantly $(\mathrm{p}<0.05)$ in tiller production. Number of produced tillers per plant declined from 2.57 to 2.47 tillers plant ${ }^{-1}$ from seeding depth of $4 \mathrm{~cm}$ to seeding depth 2 $\mathrm{cm}$. Seeding rates also affect plant tiller production significantly, as the lowest value of 2.01 tillers per plant occurred at $9 \mathrm{~g} \mathrm{~m}^{-2}$ seeding rate, whereas the highest value of 3.09 tillers per plant produced at the seeding rate $4.5 \mathrm{~g} \mathrm{~m}^{-2}$. Coleoptiles' length of wheat seedling rarely exceeds $5 \mathrm{~cm}$ in length, the deeper is seeding the less efficiency of crown formation and emergence (Heather and LA fond .1989).

\section{III-A-2- Flag leaf length $\left(\mathrm{cm}^{2}\right)$}

Significant effects imposed by seeding depths on flag leaf length. The longest leaf of $17.48 \mathrm{~cm}$ length and shortest of $17.04 \mathrm{~cm}$ occurred with $2 \mathrm{~cm}$ and $6 \mathrm{~cm}$ seeding depths respectively. Flag leaf length decreased significantly from $17.74 \mathrm{~cm}$ at $4.5 \mathrm{~g} \mathrm{~m}^{-2}$ to $16.82 \mathrm{~cm}$ at $9 \mathrm{~g} \mathrm{~m}^{-2}$ seeding rates respectively (Table-2). And decreased significantly in adverse to increasing of Seeding rates.

\section{III-A-3- Plant Leaf area $\left(\mathrm{cm}^{2}\right)$}

Plant leaf area response to seeding depth significantly. Values of this trait differed significantly by seeding depth, the extreme of $4 \mathrm{~cm}$ middle depth performed the highest plant leaf area $\left(167.67 \mathrm{~cm}^{2}\right)$ in compare to $6 \mathrm{~cm}$ depth (152.83), this contradictory results might be refers to the difference in available temperature due to delayed emergence of deepest seeds . Leaf area decreased as a response to increase of Seeding rate from $176.81 \mathrm{~cm}^{2}$ at the density of $4.5 \mathrm{~g} \mathrm{~m}^{-2}$ to $149.56 \mathrm{~cm}^{2}$ at $9 \mathrm{~g} \mathrm{~m}^{-2}$ seeding rate (table-2)

\section{III-A-4- Leaf Area Index (LAI)}

Minimum value of LAI (3.23) occurred with $6 \mathrm{~cm}$ seeding depth, in contrast to the statistically equaled highest values (3.50 to 3.51 ) obtained respectively from either 2 or 4 depths (table-2). LAI decreased inversely with Seeding rate as a result to decreasing of valid area per each single plant. The same behavior was conducted by leaf area, as the highest LAI of 4.73 occurred with Seeding rate of $4.50 \mathrm{~g} \mathrm{seeds} \mathrm{m}^{-2}$.Table- 2 also shows that lowest LAI occurred with Seeding rate of $9 \mathrm{~g}$ seeds $\mathrm{m}^{-2}$.

\section{III-A-5- Number of spikes $\mathrm{m}^{-2}$}

Table-2 shows significant differences among the average number of spikes produced at different Seeding rates, as well as significant differences among seeding depths are presented in the same table. Larger average of spikes $\mathrm{m}^{-2}$ ( 401.12 and 385.0$)$ produced as the effect of planting density $7.5 \mathrm{~g} \mathrm{seeds}^{-2}$ and seeding depth of $4 \mathrm{~cm}$ respectively. Whereas lower averages of 357 and 376.8 spikes $\mathrm{m}^{-2}$ where produced at seeding rate $7.5 \mathrm{~g} \mathrm{seeds}^{-2}$ and $4 \mathrm{~cm}$ seeding depth respectively. Increasing of tiller number and leaves per area due to increasing seeding rate leaded to slight increment in LAI.

\section{III-A-6- Number of Grains Spike ${ }^{-1}$}

Number of grains per spike decreased significantly by $0.06 \%$ when Seeding rate increased from $4.5 \mathrm{~g}$ seeds $\mathrm{m}^{-2}$ to $9 \mathrm{~g}$ seeds $\mathrm{m}^{-2}$ (table-2). While significant differences arose to only $3 \%$ in this trait values among seeding depths from $2 \mathrm{~cm}$ to $6 \mathrm{~cm}$.

\section{III-A-7- Weight of 1000 Grain Weight (TKW) g}

Table-2 shows inverse significant effect of planting densities to TKW as their effects on number of grains per spike. Superior of $39.37 \mathrm{~g}$ occurred at $6 \mathrm{~cm}$ depth seeding over lower value of TGW occurred with 2 $\mathrm{cm}$ depth. The larger and lower values were $39.27 \mathrm{~g}$ at both of the rates 7.5 and $9 \mathrm{~g} \mathrm{seeds}^{-2}$ and the lower of 
$39.23 \mathrm{~g}$ at 4.5 and $6 \mathrm{~g}$ seeds $\mathrm{m}^{-2}$ respectively. Thus the availability of larger photosynthetic substrates might be occurred for seed filling, then produce larger seed weight as a consequence (Marof 2008).

\section{III-A-8- Straw and grain yields}

Table-2 reveals significant superior Straw and grain yields of 7.33, and $3.03 \mathrm{t} \mathrm{ha}^{-1}$ occurred at the seeding rate of $7.5 \mathrm{~g}$ seeds $\mathrm{m}^{-2}$, whereas lower values of both yield types occurred at seeding rate of $6 \mathrm{~g}$ seeds $\mathrm{m}^{-2}$ possessing average values of $6.65 \mathrm{tha}^{-1}$, and $2.79 \mathrm{tha}^{-1}$ respectively. As related to seeding depths, the same table reveals also minimum averages of straw and grain yield g yields were obtained at 4 and $6 \mathrm{~cm}$ depths with values of $6.80 \mathrm{tha}^{-1}$ for straw and $2.82 \mathrm{tha}^{-1}$ of grain yield respectively.

\section{III-A-9- Harvest Index (HI)}

The superior harvest index (HI) occurred at seeding depth of $4 \mathrm{~cm}$ and rate of $6 \mathrm{~g}$ seeds $\mathrm{m}^{-2}$ as they averaged $43.08 \%$ and $42.13 \%$. Whereas, the lower values of this trait occurred at both of depths $(2$ and $6 \mathrm{~cm})$ possessing the statistically equaled averages of (40.54 and 40.93) respectively (table-2). While $4.5 \mathrm{~g}^{2}$ seeds $\mathrm{m}^{-2}$ produced a harvest index of $39.74 \%$.Harvest indices as a resultant for all independent factors and response effects reflect the overall aim to most of the agricultural practices.

\section{III-B- Effect of interaction between seeding depths and Seeding rates on some traits III-B- 1-Number of tiller Plant ${ }^{-1}$}

Table- 3 and figure-1 show significant difference in tiller plant ${ }^{-1}$ production, the highest value of 3,13 tillers plant ${ }^{-1}$ produced at the interaction of both 4 and $6 \mathrm{~cm}^{-1}$ seeding depths each $\times$ seeding rate of $4.5 \mathrm{~g}^{-1}$ seeds m

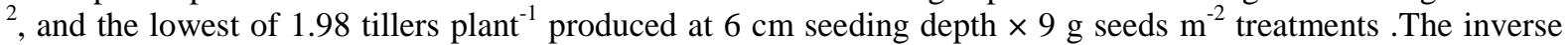
relation between tiller production by single plants and the interaction of seeding depth and Seeding rate is in accordance with Hunt 1978.

\section{III-B- 2- Flag leaf length (cm)}

Statistical significant differences were observed among flag leaf lengths ( table-3 and figure-2) .The highest value of $17.97 \mathrm{~cm}$ occurred at $2 \mathrm{~cm}$ seeding depth $\times 4.5 \mathrm{~g}$ seeds m$^{-2}$ compared to the lowest value of $16.71 \mathrm{~cm}$ at the interaction effect of $6 \mathrm{~cm}$ seeding depth $\times 9 \mathrm{~g}$ seeds $\mathrm{m}^{-2}$.

\section{III-B- 3- Plant Leaf area $\left(\mathrm{cm}^{2}\right)$}

Highest value of $187.17 \mathrm{~cm}^{2}$ flag leaf length produced from ( $4 \mathrm{~cm}$ seeding depth $\times 4.5 \mathrm{~g}^{2}$ seeds $\mathrm{m}^{-2}$ ) which differed significantly than an area of $146.0 \mathrm{~cm}^{2}$ produced from the interaction of $6 \mathrm{~cm}$ seeding depth $\times 9 \mathrm{~g}$ seeds $\mathrm{m}^{-2}$ (table-3 and figure 3 ).

\section{III-B- 4- Leaf Area Index (LAI)}

Leaf area index is also affected significantly by the interaction between seeding depth and Seeding rate, as the LAI averaged 4.97 from $4 \mathrm{~cm}$ seeding depth $\times 4.5 \mathrm{~g}$ seeds $\mathrm{m}^{-2}$, overachieved the average 2.40 that obtained from the interaction of $6 \mathrm{~cm}$ seeding depth $\times 9 \mathrm{~g}$ seeds $\mathrm{m}^{-2}$ (table-3 and figure 4 ).

\section{III-B- 5- Number of spikes $\mathbf{m}^{-2}$}

Significant differences $(\mathrm{p} \geq 0.05)$ are shown on table- 3 and figure 5 in spike production per area from 412.7 spikes $\mathrm{m}^{-2}$ at $4 \mathrm{~cm}$ seeding depth $\times 7.5 \mathrm{~g}$ seeds $\mathrm{m}^{-2}$ to 388.95 spikes $\mathrm{m}^{-2}$ at $6 \mathrm{~cm}$ seeding depth $\times 9 \mathrm{~g}$ seeds $\mathrm{m}^{-2}$.

\section{III-B- 6- Number of Grains Spike ${ }^{-1}$}

Statistical excessive performance ( $\mathrm{p} \geq 0.05$ ) of the interaction ( $2 \mathrm{~cm}$ seeding depth $\times 4.5 \mathrm{~g}$ seeds $^{-2}$ ) was recorded in table-3 and figure 6 valued 40.49 grains spike $^{-1}$, in opposite to 37.40 grains spike ${ }^{-1}$ at $6 \mathrm{~cm}$ seeding depth $\times 9 \mathrm{~g}$ seeds $\mathrm{m}^{-2}$.

\section{III-B- 7- Weight of 1000 Grains Weight (TKW) g}

Statistical analysis of data in table- 3 and figure 7 show significant differences $(\mathrm{p} \geq 0.05)$ observed in weight of thousand grains, which reached $39.43 \mathrm{~g}$ at interaction of $6 \mathrm{~cm}$ seeding depth with both seeding rates 7.5 and $9 \mathrm{~g}$ seeds $\mathrm{m}^{-2}$ with lesser average of $39.03 \mathrm{~g}$ at $2 \mathrm{~cm}$ seeding depth $\times 6 \mathrm{~g}$ seeds $\mathrm{m}^{-2}$.

\section{III-B- 8- Straw and grain yield $\mathrm{g} \mathrm{m}^{-2}$}

Grain yield in table- 3 and figure 8 possessed $3.12 \mathrm{t} \mathrm{ha}^{-1}$ at $4 \mathrm{~cm}$ seeding depth $\times 7.5 \mathrm{~g} \mathrm{~m}^{-2}$ seeding rate, and over yielded the interaction effect of the combination $6 \mathrm{~cm}$ seeding depth $\times 6 \mathrm{~g} \mathrm{~m}^{-2}$ seeding rate, that produced $2.74 \mathrm{tha}^{-1}$. While straw yield average $7.43 \mathrm{tha}^{-1}$ yielded from the interaction of $6 \mathrm{~cm}$ seeding depth 
and $7.5 \mathrm{~g} \mathrm{~m}^{-2}$ rate over yielded $6.32 \mathrm{t} \mathrm{ha}^{-1}$ significantly that occurred with $4 \mathrm{~cm}$ depth $\times 6 \mathrm{~g} \mathrm{~m}^{-2}$ seeding rate. The similar trend of both of straw yield and grain yield at the same seeding depth, and Seeding rate combination might occurred due to having a single wheat cultivar Semito (figure 9) .

\section{III-B- 9- Harvest Index (HI)}

Significant effects of the interaction between (seeding depth $\times$ Seeding rate) are occurred as shown on table-3 and figure 10 .The highest $\mathrm{HI}$ of $44.45 \%$ was performed from the interaction ( $4 \mathrm{~cm}$ seeding depth $\times 9 \mathrm{~g}$ $\mathrm{m}^{-2}$ ), and the lowest $\mathrm{HI}$ averaged $38.55 \%$ and occurred at $2 \mathrm{~cm}$ seeding depth $\times 4.5 \mathrm{~g} \mathrm{~m}^{-2}$ seeding rate ( figure 10)

\section{III-C- Manipulation of Surfer- 8 program}

Figures from 1 to 10 are representing the Surfer presentation of the effects of the interaction between seeding depths and Seeding rates on the studied traits as referred previously, each figure represents one trait response in both of $2 \mathrm{D}$ and $3 \mathrm{D}$ as contour lines. Models build between trait responses and independent factors ( $\mathrm{y}=$ seeding rate and $\mathrm{x}=$ planting depth) based on polynomial regressions using Surfer- 8 program have similar values to the reciprocal models that had obtained by SAS program. Figure 5 shows some other flexible ability of the program as showing perspective plan or highlighting maximum and minimum values with different line colors or thickness and maximizing or minimizing font size and dentations of the scales. More capable versions of surfer as (Surfer-10) versions are available nowdays.

\section{Conclusion and recommendation}

Seeding depths and rates had and will have important affects on growth and yield of wheat in spite of all the studies from the earliest years of scientific agriculture .Surfer program provides a statistical and presenting aid with more efficient in some faces than the normal procedures and some of the newly computerized aids.

\section{Acknowledgment}

We would like to thank engineer Maqsud / chief of ( Erbil research center - Kurdistan regional government) and his staff for their kind assistance.

\section{References}

[1]. Anter, Salim Humadi . 2010. Statistical Analysis in Scientific Research and SAS Program . University of Mousel. ( In Arabic).

[2]. Heather Loeppky and G. P. Lafond .1989. Seeding Depth in Relation to Plant Development, Winter Survival, and Yield of No-Till Winter Wheat. Agron Jornal 81 125.USA

[3]. Hunt 1978. (C.F , Hasan Kilic, and Songul Gursoy. 2010. Effect of seeding rate on yield and yield components of durum wheat cultivars in cotton - wheat cropping system. Scientific Research and Essays Vol. 5(15), pp.2078 - 2084, August, 2010. ISSN 1992 -2248 @ 2010 Academic journals.

[4]. Khan Imran, Abbas Ullah Jan, Farhana Gul1, Kawsar Ali, Ghaffar Ali, Sajjad Ahmed and Naveed Ahmad 2011.WEEDS AS A MAJOR CONSTRAINT IN WHEAT PRODUCTION IN DISTRICT PESHAWAR. Pak. J. Weed Sci. Res. 17(4) 381-386, 2011.

[5]. Marof .S.M. 2008.Competitive Interference Between Triticale and Wheat Under Two Different Environmental Conditions. Ph. D. dissertation. College of Agriculture. University of Salahaddin.

[6]. Paul L. MASK.2008. Alabama Wheat Production Guide. Alabama cooperative extension. Barley drying.ANR-92.

[7]. SAS Institute. 2002. SAS user guide Statistics, Cary, NC 27013, USA. SAS (r) Proprietary Software Version (TS P1) North Carolina State University, Site 0027585007.

[8]. Surfare-8, 2002, Surfer-8 mapping system, Golden Software, Inc. Golden, Colorado 80401-1866. USA

[9]. Zadoks, J.C.,T.T Chang and C.F. Zonzak. (1974). A decimal code for the growth stages of cereals. Wee Res. $14415-421$.

Table (1) Meteorological data for Ainkawa research station during the rainfall seasons of (2009-2010)

\begin{tabular}{|c|c|c|c|c|c|c|c|c|c|c|}
\hline \multirow{2}{*}{\multicolumn{2}{|c|}{$\begin{array}{c}\text { Parameter } \\
\text { Month }\end{array}$}} & \multicolumn{3}{|c|}{ Year 2009} & \multicolumn{5}{|c|}{ Year 2010} & \multirow[t]{2}{*}{ Total } \\
\hline & & Oct & Nov & Dec & Jan & Feb & Mar & April & May & \\
\hline \multicolumn{2}{|c|}{ Monthly rainfall $\mathrm{mm}$} & 53 & 19 & 38 & 0.9 & 22.7 & 31.1 & 36.8 & 0.0 & $201.5 \mathrm{~mm}$ \\
\hline \multirow{3}{*}{$\begin{array}{c}\text { Air } \\
\text { Temperature }\end{array}$} & $\operatorname{Max}$ & 30.5 & 18.5 & 15.9 & 13 & 17.5 & 23 & 25 & 31 & \\
\hline & Min & 17.5 & 13 & 6.36 & -1.5 & 7 & 12 & 13 & 21 & \\
\hline & Average & 23.5 & 15.6 & 9.76 & 7.2 & 11.5 & 14.5 & 17.6 & 25.8 & \\
\hline \multirow{3}{*}{$\begin{array}{l}\text { Air relative } \\
\text { Humidity\% }\end{array}$} & $\operatorname{Max}$ & 86.5 & 83 & 95.6 & 96.5 & 93.5 & 97 & 76.5 & 63.5 & \\
\hline & Min & 32.8 & 54 & 65.7 & 30.3 & 56.3 & 62 & 22.5 & 21.8 & \\
\hline & Average & 60.5 & 71.5 & 81.4 & 59.3 & 36.3 & 81 & 51.8 & 43.5 & \\
\hline \multicolumn{2}{|c|}{ Wind velocity $\mathrm{m} \mathrm{sec}^{-1}$} & 10.8 & 11.1 & 10.7 & 11 & 8.5 & 8.7 & 7.5 & 6.5 & \\
\hline \multicolumn{2}{|c|}{ Sunshine duration hr day ${ }^{-1}$} & 6.8 & 6.4 & 6.2 & 5.5 & 6.5 & 7.1 & 7.4 & 9.0 & \\
\hline \multicolumn{2}{|c|}{ Evaporation ml day } & 5.7 & 1.3 & 1.8 & 1.5 & 2.6 & 4.5 & 5 & 9.5 & \\
\hline \multicolumn{11}{|c|}{ From Agro meteorological monthly bulletin / MOA/GD of Agriculture / Erbil } \\
\hline
\end{tabular}


Table (2) - Effects of seeding depths and Seeding rate on ten studied traits

\begin{tabular}{|c|c|c|c|c|c|c|c|c|c|}
\hline \multirow{2}{*}{$\begin{array}{c}\text { Factors } \\
\text { Treatments }\end{array}$} & \multicolumn{3}{|c|}{ Seeding depth $\mathrm{cm}$} & \multirow{2}{*}{$\begin{array}{c}\text { LSD } \\
0.05\end{array}$} & \multicolumn{4}{|c|}{ seeding rates } & \multirow{2}{*}{$\begin{array}{c}\text { LSD } \\
0.05\end{array}$} \\
\hline & $2 \mathrm{~cm}$ & $4 \mathrm{~cm}$ & $6 \mathrm{~cm}$ & & $4.5 \mathrm{~g} \mathrm{~m}^{-2}$ & $6.0 \mathrm{~g} \mathrm{~m}^{-2}$ & $7.5 \mathrm{~g} \mathrm{~m}^{-2}$ & $9.0 \mathrm{~g} \mathrm{~m}^{-2}$ & \\
\hline Tiller plant ${ }^{-1}$ & 2.47 & 2.57 & 2.48 & 0.024 & 3.09 & 2.53 & 2.32 & 2.01 & 2.4861 \\
\hline $\begin{array}{l}\text { Flag leaf } \\
\text { length cm }\end{array}$ & 17.48 & 17.29 & 17.04 & 0.049 & 17.74 & 17.37 & 17.17 & 16.82 & 0.56 \\
\hline $\begin{array}{c}\text { Leaf area } \\
\mathrm{cm}^{2}\end{array}$ & 166.8 & 167.67 & 152.83 & 0.8 & 176.81 & 163.6 & 159.77 & 149.56 & 0.93 \\
\hline LAI & 3.5 & 3.51 & 3.23 & 0.02 & 4.73 & 3.54 & 2.92 & 2.46 & 0.02 \\
\hline Spike $\mathbf{m}^{-2}$ & 377.2 & 385 & 376.8 & 3.63 & 357.87 & 365.45 & 401.12 & 394.26 & 4.19 \\
\hline $\begin{array}{l}\text { Grains } \\
\text { spike }^{-1}\end{array}$ & 39.37 & 38.66 & 38.08 & 0.11 & 39.78 & 38.94 & 38.43 & 37.67 & 38.7 \\
\hline $\begin{array}{c}1000 \\
\text { Grain } \\
\text { weight g }\end{array}$ & 39.05 & 39.34 & 39.38 & 39.25 & 39.23 & 39.23 & 39.27 & 39.27 & 0.27 \\
\hline $\begin{array}{c}\text { Grain yield } \\
\mathrm{t} \mathrm{ha}^{-1}\end{array}$ & 2.89 & 2.93 & 2.82 & 0.3 & 2.791 & 2.891 & 3.026 & 2.917 & 0.125 \\
\hline $\begin{array}{c}\text { Straw yield } \\
\mathrm{t} \mathrm{ha}^{-1}\end{array}$ & 7.08 & 6.8 & 6.99 & 0.166 & 7.024 & 6.65 & 7.328 & 6.821 & 0.191 \\
\hline $\mathrm{HI} \%$ & 40.93 & 43.08 & 40.54 & 0.8 & 39.74 & 42.13 & 41.37 & 42.84 & 0.125 \\
\hline
\end{tabular}

Table (3) Effects of ( seeding depth $\mathrm{x}$ seeding rate) interaction on ten studied traits of wheat

\begin{tabular}{|c|c|c|c|c|c|c|c|c|c|c|c|}
\hline 竎 & Treatments & $\begin{array}{l}\text { Tiller } \\
\text { plant }^{-1}\end{array}$ & $\begin{array}{c}\text { Flag leaf } \\
\text { length } \mathbf{c m}^{2}\end{array}$ & $\begin{array}{c}\text { Leaf } \\
\text { area } \\
\mathrm{cm}\end{array}$ & LAI & $\begin{array}{l}\text { Grain } \\
\text { spike }^{-1}\end{array}$ & $\begin{array}{c}\text { Spike } \\
\mathbf{m}^{-2}\end{array}$ & TGW & $\begin{array}{c}\text { Grain yield } \\
\text { t ha }^{-1}\end{array}$ & $\begin{array}{c}\text { Straw } \\
\text { yield } \\
\text { t ha-1 }\end{array}$ & HI\% \\
\hline \multirow{12}{*}{ 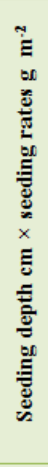 } & $2 \mathrm{~cm} \times 4.5 \mathrm{~g}$ & 3.02 & 17.97 & 182.97 & 4.87 & 40.49 & 346.90 & 39.05 & 2.74 & 7.12 & 38.55 \\
\hline & $2 \mathrm{~cm} \times 6 \mathrm{~g}$ & 2.55 & 17.77 & 170.20 & 3.65 & 39.98 & 366.95 & 39.03 & 2.86 & 7.07 & 40.48 \\
\hline & $2 \mathrm{~cm} \times 7.5 \mathrm{~g}$ & 2.30 & 17.27 & 162.57 & 2.97 & 38.87 & 398.85 & 39.05 & 3.02 & 7.27 & 41.68 \\
\hline & $2 \mathrm{~cm} \times 9 \mathrm{~g}$ & 2.00 & 16.93 & 151.47 & 2.50 & 38.13 & 396.00 & 39.05 & 2.95 & 6.85 & 43.02 \\
\hline & $4 \mathrm{~cm} \times 4.5 \mathrm{~g}$ & 3.13 & 17.92 & 187.17 & 4.97 & 40.06 & 365.20 & 39.35 & 2.88 & 7.03 & 40.95 \\
\hline & $4 \mathrm{~cm} \times 6 \mathrm{~g}$ & 2.53 & 17.25 & 167.33 & 3.60 & 38.58 & 364.30 & 39.36 & 2.77 & 6.32 & 43.80 \\
\hline & $4 \mathrm{~cm} \times 7.5 \mathrm{~g}$ & 2.37 & 17.22 & 164.97 & 3.00 & 38.48 & 412.70 & 39.33 & 3.12 & 7.24 & 43.13 \\
\hline & $4 \mathrm{~cm} \times 9 \mathrm{~g}$ & 2.03 & 16.80 & 151.20 & 2.48 & 37.48 & 397.80 & 39.32 & 2.93 & 6.59 & 44.45 \\
\hline & $6 \mathrm{~cm} \times 4.5 \mathrm{~g}$ & 3.12 & 17.33 & 160.30 & 4.35 & 38.77 & 361.50 & 39.30 & 2.77 & 6.92 & 39.71 \\
\hline & $6 \mathrm{~cm} \times 6 \mathrm{~g}$ & 2.52 & 17.10 & 153.27 & 3.37 & 38.25 & 365.10 & 39.35 & 2.74 & 6.56 & 42.10 \\
\hline & $6 \mathrm{~cm} \times 7.5 \mathrm{~g}$ & 2.28 & 17.02 & 151.77 & 2.80 & 37.92 & 391.80 & 39.43 & 2.92 & 7.43 & 39.30 \\
\hline & $6 \mathrm{~cm} \times 9 \mathrm{~g}$ & 1.98 & 16.71 & 146.00 & 2.40 & 37.40 & 388.95 & 39.43 & 2.87 & 7.01 & 41.05 \\
\hline & LSD $_{0.05}$ & 0.049 & 0.097 & 1.60 & 0.04 & 0.214 & 7.26 & 0.047 & 0.059 & 0.331 & 1.595 \\
\hline
\end{tabular}

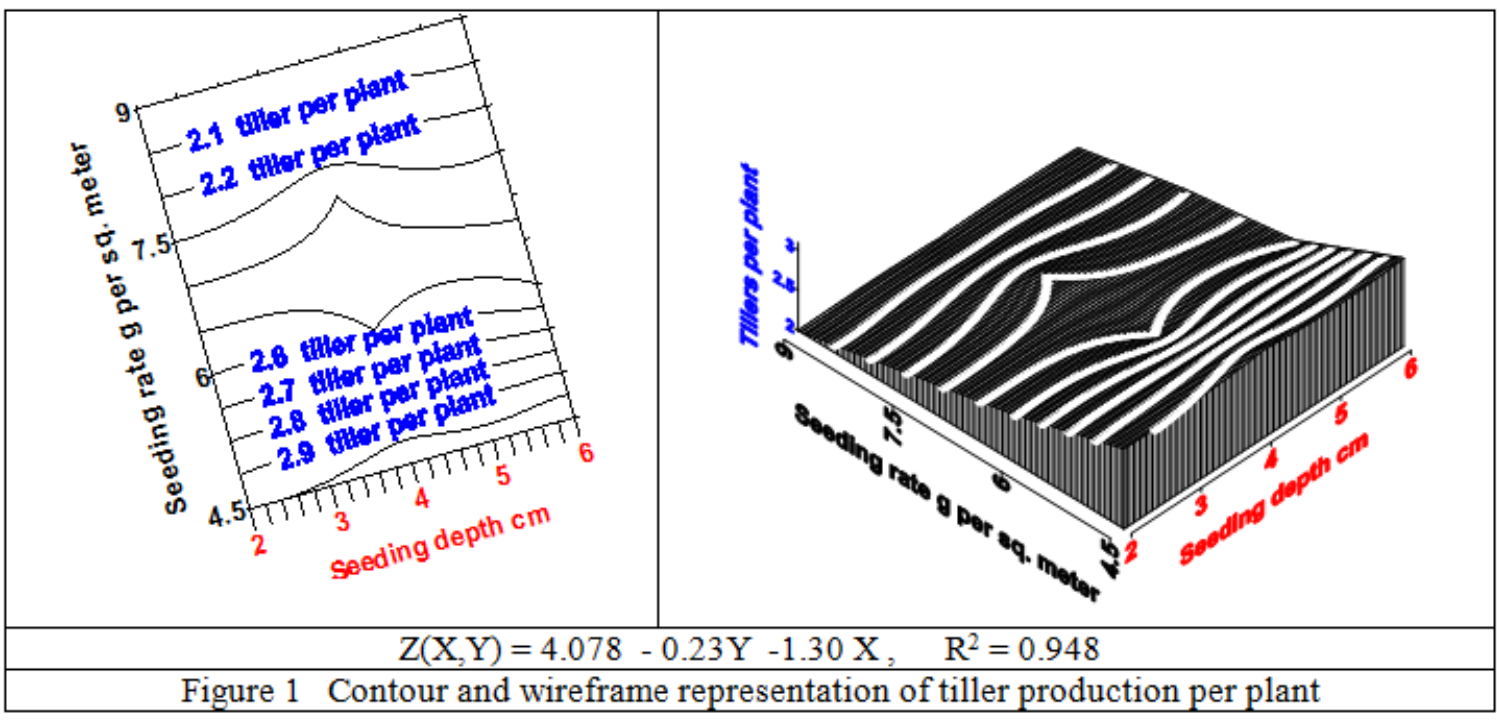



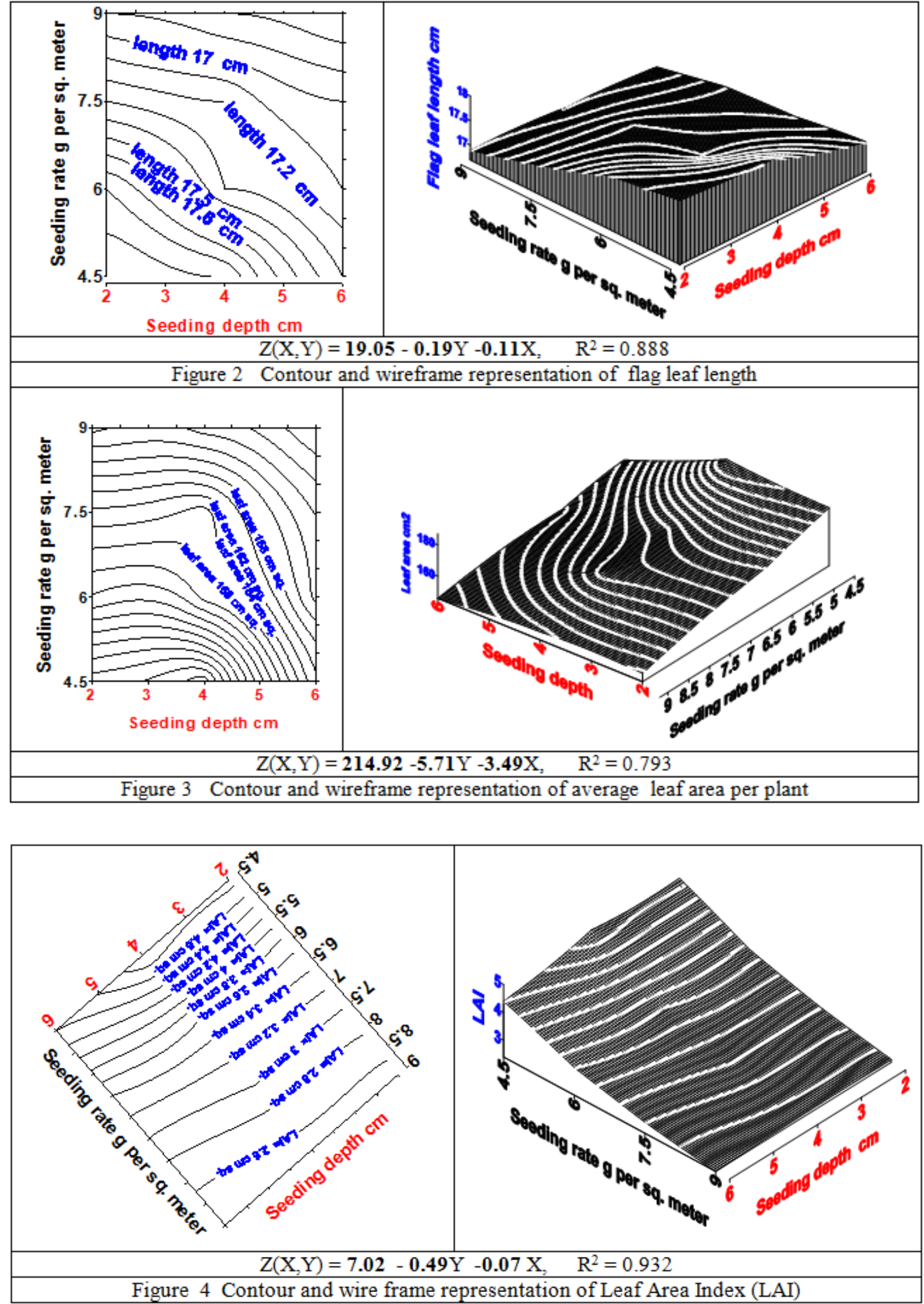

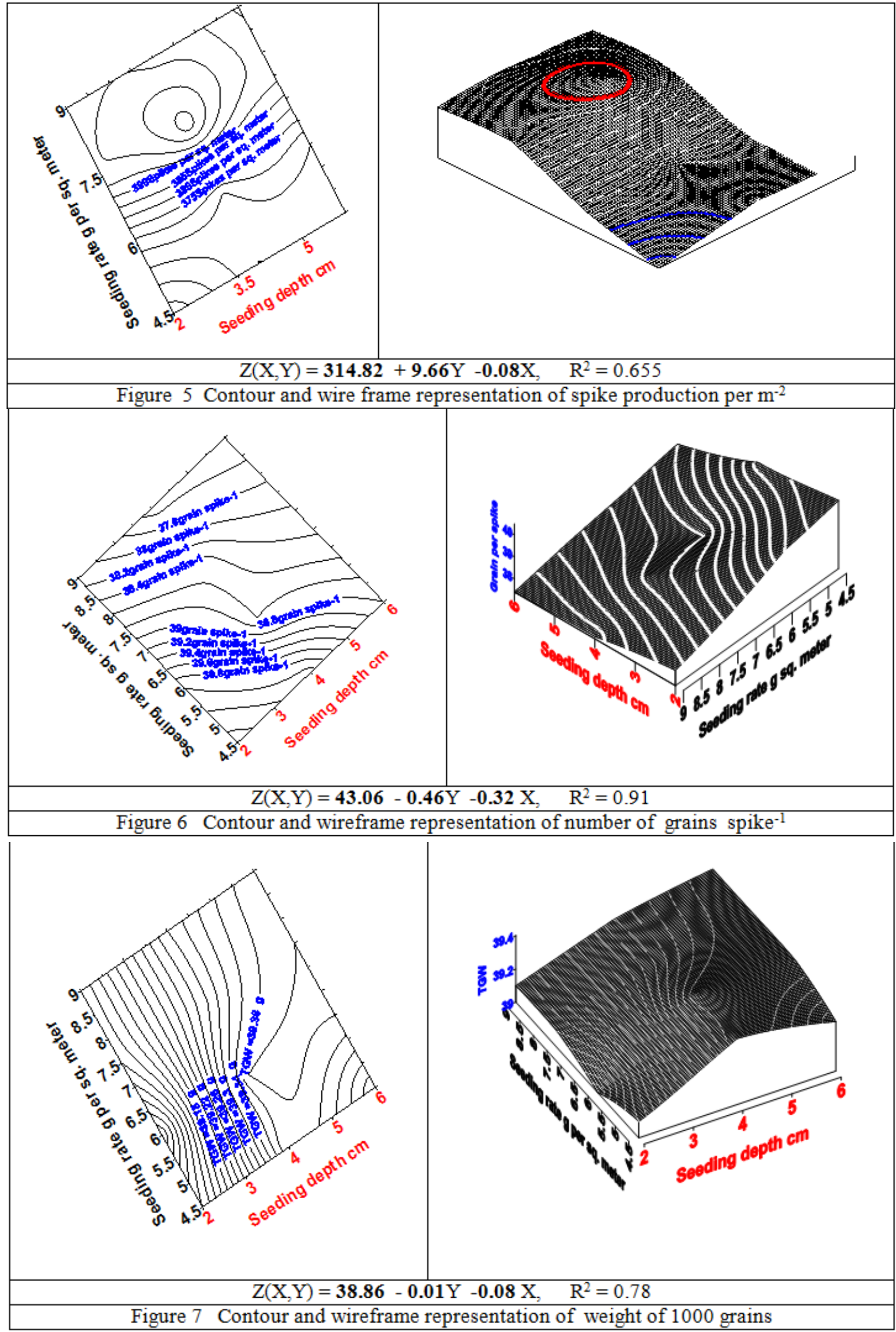

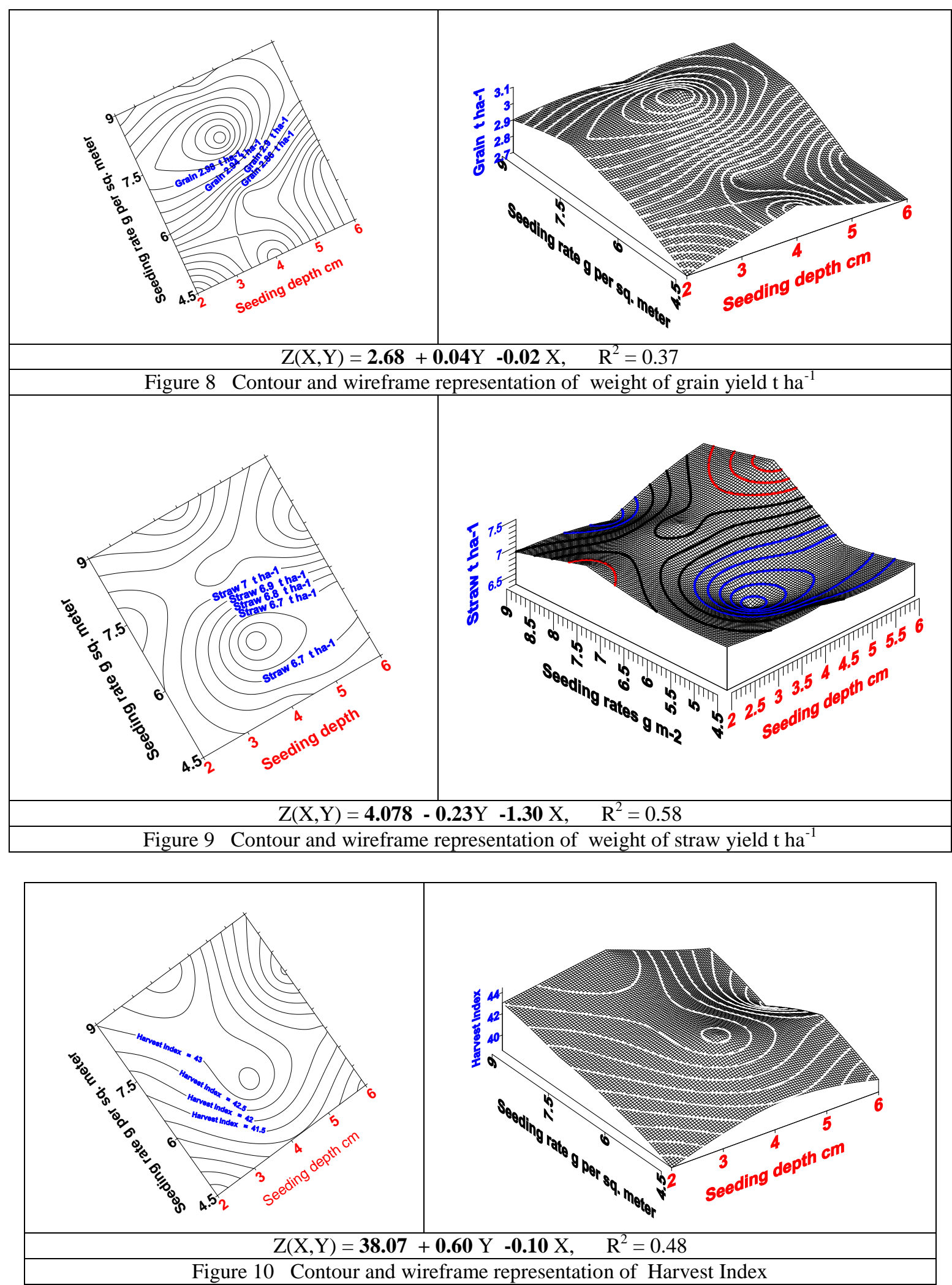